\title{
Seroprevalence of SARS-CoV-2 antibodies among physicians from a children's hospital
}

\author{
Claudia Insúa, B.S. ${ }^{* a}$, Graciela Stedile, M.D. ${ }^{*}$, Verónica Figueroa, M.D. ${ }^{a}$, \\ Claudia Hernández, M.D. ${ }^{a}$, Alejandra Svartz, Biochemist ${ }^{b}$, Fernando Ferrero, M.D. ${ }^{c}$, \\ María F. Ossorio, M.D. ${ }^{d}$ and Oscar Brunetto, M.D. ${ }^{a}$
}

\begin{abstract}
Introduction. In just a few months, coronavirus disease 2019 (COVID-19) has become a pandemic, causing millions of cases and hundreds of thousands of deaths. Due to its high infectiousness, the health care staff is even more exposed. Nevertheless, there is still very limited information about it, especially among pediatricians.

Objective. To assess the seroprevalence of SARSCoV-2 antibodies among physicians from a children's hospital 3 months after the first case in Argentina. To explore if certain demographic, occupational, and epidemiological characteristics are risk factors for SARS-CoV-2 seropositivity. Methods. Cross-sectional study of physicians randomly selected from the list of workers of a children's hospital. All of them were screened for SARS-CoV-2 antibodies by chemiluminescence (immunoglobulins G/M [IgG/IgM]) and their epidemiological history was collected (age, place of residence, professional category, contact with infected people)in order to explore the association between predictors and seropositivity.

Results. A total of 116 physicians were included; their average age was $45.6 \pm 13.3$ years. Of them, $62.9 \%$ werestaff physicians, and the rest, residents; $42.2 \%$ worked in areas designated for direct care ofCOVID-19 patients. Four (3.5\%) referred contact with infected people without the appropriate protection, and $6(5.2 \%)$, having traveled to risk areas. SARS-CoV-2 antibodies (IgG) were only detected in one of the professionals. Because of this, it was impossible to assess the association between potential predictors and the presence of SARS-CoV-2 antibodies.

Conclusion. It was observed that only $0.9 \%$ of the physicians from a children's hospital had SARS-CoV-2 antibodies.

Key words: coronavirus infections, COVID-19, prevalence, health care staff.
\end{abstract}

http: / / dx.doi.org/10.5546/ aap.2020.eng.381

To cite: Insúa C, Stedile G, Figueroa V, Hernández C, et al.Seroprevalence of SARS-CoV-2 antibodies among physicians from a children's hospital. Arch Argent Pediatr 2020;118(6):381-385.

\section{INTRODUCTION}

On December 31 $1^{\text {st }}, 2019$, the World Health Organization (WHO) was informed of cases of pneumonia of unknown cause being detected in Wuhan, China. The outbreak was declared a public health emergency of international concern on January $30^{\text {th }}$, 2020. On February $11^{\text {th }}$, 2020, the WHO announced the name of the novel coronavirus disease: coronavirus disease 2019 (COVID-19). ${ }^{1}$

In just a few months, the geographic distribution of the disease was so wide that it became the most important pandemic that humanity has suffered in the last 50 years, with millions of cases and tens of thousands of deaths. ${ }^{2}$ In addition, given the current characteristics of communication and transportation, it has had a very important impact on society. ${ }^{3}$

The high transmission capacity of this virus makes the health care staff especially vulnerable to its infection, particularly when appropriate measures are not taken. ${ }^{4}$ There are detailed guidelines on the use of personal protective equipment (PPE) according to the level of exposure of the health care staff in different areas. ${ }^{5}$

Although it is reasonable to think that, with the unfolding of the pandemic, part of the health care staff will get infected, there is still very limited information about it, ${ }^{6,7}$ especially in relation to pediatricians. Despite the evidence showing that the disease seems to have a milder course in children than in other age ranges, ${ }^{8}$ there are still doubts regarding their role in the spread of the disease. ${ }^{9}$

Having better information on the proportion of members of the health 
care staff that get infected will help to develop better policies to face this and other pandemics, and protect those who deal directly with it on a daily basis. Our objective was to assess the seroprevalence of antibodies against the severe acute respiratory syndrome coronavirus 2 (SARSCoV-2) among physicians from a children's hospital and explore if certain demographic, work, and epidemiological characteristics were risk factors for SARS-CoV-2 seropositivity.

\section{POPULATION AND METHODS}

Design: Cross-sectional study. A descriptive approach was adopted for the primary objective and an analytic approach, for the exploratory one (risk).

Population: Staff physicians and residents from Hospital General de Niños Pedro de Elizalde (HGNPE).

Outcome variable: Presence of SARS-CoV-2 antibodies (immunoglobulin G [IgG] and/or immunoglobulin M [IgM]).

Predictor variables (exploratory): Age, place of residence (Autonomous City of Buenos Aires or province of Buenos Aires), professional category (staff physician/resident), department (Medicine, Emergency, Outpatient Clinic, Surgery, Diagnostics, Teaching and Research), area caring for COVID-19 patients (yes/no), professional contact (close contact with patients diagnosed with COVID-19 without appropriate protection as part of their professional activity), social contact (close contact with people diagnosed with COVID-19 without appropriate protection outside of their professional activity), and history of travel to areas with virus circulation before 3/16/2020 (USA, Korea, China, Japan, Iran, Europe, Brazil, Chile).

Sample size calculation: Considering that approximately 600 physicians were part of the hospital's staff and expecting a $10 \% \pm 5 \%$ prevalence of seropositivity, 112 determinations were required to estimate that prevalence with a $95 \%$ confidence level.

Sampling: Upon approval from the Research Ethics Committee, the Human Resources Office and the Department of Education and Research were asked for the complete list of physicians (both staff physicians and residents) who worked at the hospital by April $30^{\text {th }}, 2020$. This list, which was ordered alphabetically, was used to estimate the sampling fraction, and a systematic sampling with random start was performed to cover the number of required determinations. Selected professionals were invited to participate and give their informed consent. If they refused to participate or the sample could not be obtained, the immediately following one in the list was invited to participate.

Statistical processing: The prevalence of SARS-CoV-2 seropositivity was estimated for the entire population with the corresponding $95 \%$ confidence interval (95\% CI). We considered assessing the potential association between predictors and the outcome variable using the $\chi^{2}$ test, but this was not possible given the extremely low prevalence of SARS-CoV-2 antibodies. IBM SSPS Statistics 20.0 was used for data processing.

Sample collection: Blood samples of $4 \mathrm{~cm}^{3}$ were obtained by venipuncture. They were placed in gel-barrier tubes, with a cap, and left at room temperature for 2 hours; they were then centrifuged at 4500 revolutions per minute (rpm) during 15 minutes. Serum was separated. All blood collections were performed on June $8^{\text {th }}$ and $9^{\text {th }}, 2020$, to limit the bias related to disease exposure time.

Diagnostic test: All samples were processed at the same time. The determination of anti-SARSCoV-2 antibodies (IgG and IgM) was performed simultaneously for both immunoglobulins using automated qualitative indirect chemiluminescence in human serum, ${ }_{1}^{10}$ with the MAGLUMI 2019-nCoV IgM and 2019-nCoV IgG (CLIA) systems from Snibe. According to the manufacturer, their system showed a sensitivity of $95.6 \%$ and a specificity of $96 \%$ (IgG and IgM) (Shenzhen New Industries Biomedical Engineering Co., Shenzhen, China). Results were interpreted as follows: $<1 \mathrm{AU} / \mathrm{mL}=$ non-reactive and $\geq 1 \mathrm{AU} / \mathrm{mL}=$ reactive.

Ethical considerations: The study followed Good Clinical Practice Guidelines, the Declaration of Helsinki, and the applicable rules of the Government of the Autonomous City of Buenos Aires. The approval of the hospital's Board and Research Ethics Committee was requested and obtained. An informed consent for study participation was obtained from subjects. Test results were communicated to participants in a confidential manner.

\section{RESULTS}

Out of the 672 physicians included in the hospital's list, samples of 116 individuals were studied (17.2\%). Physician's average age was $45.6 \pm 13.3$ years old. Of them, $62.9 \%$ were staff physicians from 6 different departments; $42.2 \%$ 
worked in areas designated for care of COVID-19 patients. COVID-19-related epidemiological history was very rare (Table 1).

SARS-CoV-2 antibodies (IgG) were only detected in one of the professionals (0.9\%; $95 \%$ CI: 0.1-5.5). IgM antibodies were not identified in any of them. Given that antibodies were only found in one physician, it was impossible to assess the association between potential predictors and the presence of SARS-CoV-2 antibodies (IgG or IgM).

\section{DISCUSSION}

This study found a $0.9 \%$ seroprevalence of SARS-CoV-2 antibodies among physicians from a children's hospital. Our results were much lower than that reported by Garcia-Basteiro et al. in a hospital from Barcelona. ${ }^{11}$ They observed that up to $11.2 \%$ of the health care workers from their institution had specific antibodies.

Although the low prevalence of SARS-CoV-2 seropositivity observed among physicians from our hospital may be striking, some considerations might help to explain it. Argentina's first COVID-19 case was diagnosed on 3/3/2020, and the first death occurred on $3 / 7 / 2020$. Just 13 days afterwards, the country adopted a preventive and mandatory lockdown of massive proportions. ${ }^{12}$ Since then, the National Ministry of Health ${ }^{13}$ and the Ministry of Health of the Autonomous City of Buenos Aires ${ }^{14}$ established strict protocols for health care workers, which specifically addressed personal protection. Although there are still doubts about PPE effectiveness, ${ }^{15}$ it is quite likely that these two measures, which were adopted in an early manner, might have been important to prevent our physicians from following the same fate as their Spanish ${ }^{7}$ and North American ${ }^{16}$ colleagues.

In addition to national and local rules, the hospital established a rock-solid contingency plan, which included PPE provision, staff training, a circuit for managing COVID-19 patients, specific areas for their hospitalization, the creation of teams to work alternatively, and the creation of a crisis committee to coordinate all actions. This was complemented with the deployment of an Emergency Fever Unit and a Temporary Isolation Unit at the entrance of the hospital to collaborate with the adequate screening of patients. ${ }^{17}$

In addition, it is worth recalling that one of

TABLE 1. Characteristics of the population screened for antibodies against the severe acute respiratory syndrome coronavirus 2

\begin{tabular}{|c|c|c|}
\hline & & n $(\%)$ \\
\hline Place of residence & $\begin{array}{l}\text { Autonomous City of Buenos Aires } \\
\text { Province of Buenos Aires }\end{array}$ & $\begin{array}{l}85(73.3) \\
31(26.7)\end{array}$ \\
\hline Professional category & $\begin{array}{l}\text { Staff physician } \\
\text { Resident }\end{array}$ & $\begin{array}{l}73(62.9) \\
43(37.1)\end{array}$ \\
\hline Department & $\begin{array}{l}\text { Education and Research }{ }^{* * * *} \\
\text { Outpatient Clinic } \\
\text { Emergency } \\
\text { Medicine } \\
\text { Surgery } \\
\text { Pathology }\end{array}$ & $\begin{array}{l}47(40.5) \\
25(21.6) \\
17(14.7) \\
16(13.8) \\
9(7.8) \\
2(1.7)\end{array}$ \\
\hline Work in a COVID-19 area & $\begin{array}{l}\text { Yes } \\
\text { No }\end{array}$ & $\begin{array}{l}49(42.2) \\
67(57.8)\end{array}$ \\
\hline Professional contact* & $\begin{array}{l}\text { Yes } \\
\text { No }\end{array}$ & $\begin{array}{l}3(2.6) \\
113(97.4)\end{array}$ \\
\hline Social contact ${ }^{* *}$ & $\begin{array}{l}\text { Yes } \\
\text { No }\end{array}$ & $\begin{array}{l}1(0.9) \\
115(99.1)\end{array}$ \\
\hline Travel $^{* * *}$ & $\begin{array}{l}\text { Yes } \\
\text { No }\end{array}$ & $\begin{array}{l}6(5.2) \\
110(94.8)\end{array}$ \\
\hline
\end{tabular}

* Close contact with patients diagnosed with COVID-19 without appropriate protection as part of their professional activity.

** Close contact with people diagnosed with COVID-19 without appropriate protection outside of their professional activity.

*** History of travel to areas with virus circulation before 3/16/2020 (USA, Korea, China, Japan, Iran, Europe, Brazil, Chile).

**** It includes residents.

COVID-19: coronavirus disease 2019. 
the consequences of social isolation strategies is the reduced attendance of patients to hospitals, which decreases the likelihood of transmission during those visits. This was really striking in our institution, where, for instance, Emergency Department visits decreased by more than $80 \%$ after the adoption of social isolation..$^{18}$ Lastly, children may not have the transmission capacity that was initially suspected and, what is more, their infectiousness may be lower than that of adults. ${ }^{19}$

A limitation of this study is that its population was composed exclusively of physicians, which may underestimate seroprevalence among other members of the health care team. Nevertheless, the information available to date shows that the prevalence of seropositivity within the health care staff is higher among physicians and nurses, and similar between both groups. ${ }^{20}$

It should also be considered that the ongoing pandemic has collapsed the diagnostic testing industry, due to the strict requirements of these systems. The capacity of these tests needs to be verified under international standards, such as EP15 A3 (analytical performance declared by the manufacturer) and EP12 A2 (diagnostic sensitivity and specificity declared by the manufacturer) from the Clinical and Laboratory Standards Institute (CLSI). In this study in particular, analytical performance as per EP15 A3 could be verified before using the chosen method.

Finally, as with all the information regarding this pandemic, we should be very cautious when interpreting it because of the novelty of the situation. We should wait for the results of more extensive epidemiological studies, controlling virus circulation, in order to get a clearer picture of the topic.

Our study suggests that, three months after the beginning of the pandemic, with approximately 150 patients admitted due to COVID-19 (and many of their caregivers also being infected) in our hospital, the transmission rate among physicians is very low. Four other physicians who had COVID-19 in the last 2 months should be added to the observed seroprevalence. Although the pandemic seems to be expanding across Argentina, this information may show that some of the measures adopted to face it may be adequate.

\section{CONCLUSION}

Three months after the first COVID-19 case in Argentina, only $0.9 \%$ of physicians from a children's hospital were observed to have SARSCoV-2 antibodies. Given the low prevalence, it was impossible to assess its association with potential predictors. The implemented precautionary measures may account for the low prevalence observed.

\section{Acknowledgments}

We would like to thank José Manuel Vera, M.D., and Juan Rébori, M.D., for their selfless help in sample processing.

\section{REFERENCES}

1. World Health Organization. Coronavirus disease (COVID-19) outbreak. 2020. [Accessed on: April 28 ${ }^{\text {th }}$, 2020]. Available at: https:/ / www.who.int/emergencies / diseases / novel-coronavirus-2019.

2. World Health Organization. Coronavirus Disease 2019 (COVID-19) Situation Report - 99. 2020). [Accessed on: April 28 ${ }^{\text {th }}$,2020]. Available at:https: / / www.who.int/docs/ default-source / coronaviruse / situation-reports / 20200428sitrep-99-COVID-19.pdf?sfvrsn=119fc381_2.

3. Khan S, Siddique R, Ali A, Bai Q, et al. The spread of novel coronavirus has created an alarming situation worldwide. J Infect Public Health. 2020; 13(4):469-71.

4. Heinzerling A, Stuckey MJ, Scheuer T, Xu K, et al. Transmission of COVID-19 to Health Care Personnel During Exposures to a Hospitalized Patient-Solano County, California, February 2020. MMWR Morb Mortal Wkly Rep. 2020; 69(15):472-6.

5. Centers for Disease Control and Prevention. Coronavirus Disease 2019 (COVID-19). Using Personal Protective Equipment (PPE). [Accessed on: July $28^{\text {th }}, 2020$ ]. Available at: https: / / www.cdc.gov/ coronavirus / 2019-ncov/hcp / using-ppe.html.

6. Wu Z, McGoogan JM. Characteristics of and Important Lessons From the Coronavirus Disease 2019 (COVID-19) Outbreak in China: Summary of a Report of 72314 Cases From the Chinese Center for Disease Control and Prevention. JAMA. 2020; 323(13):1239-42.

7. Minder R, Peltier E. Virus Knocks Thousands of Health Workers Out of Action in Europe. New York Times. 2020 March 24. [Accessed on: May $\left.3^{\text {rd }}, 2020\right]$. Available at: https: / / www.nytimes.com/2020/03/24/world/europe/ coronavirus-europe-covid-19.html.

8. Ludvigsson JF. Systematic review of COVID-19 in children shows milder cases and a better prognosis than adults. Acta Paediatr. 2020; 109(6):1088-95.

9. Dong $\mathrm{Y}, \mathrm{Mo} \mathrm{X}, \mathrm{Hu} \mathrm{Y}, \mathrm{Qi}$ X, et al. Epidemiology of COVID-19 Among Children in China. Pediatrics. 2020; 145(6):e20200702.

10. Padoan A, CosmaC, Sciacovelli L, FaggianD, etal. Analytical performances of a chemiluminescence immunoassay for SARS-CoV-2 IgM/IgG and antibody kinetics. Clin Chem Lab Med. 2020; 58(7):1081-8.

11. Garcia-Basteiro A, Moncunill G, Tortajada M, Vidal M, et al. Seroprevalence of antibodies against SARS-CoV-2 among health care workers in a large Spanish reference hospital. Nat Commun. 2020; 11(1):3500.

12. Boletín Oficial dela República Argentina. Decreto 297/ 2020. Aislamiento social preventivo y obligatorio. [Accessed on: June $16^{\text {th }}, 2020$ ]. Available at: https: / / www.boletinoficial. gob.ar/detalleAviso/primera/227042/ 20200320.

13. Ministerio de Salud de la República Argentina. Recomendaciones para equipos de salud. [Accessed on: 
June $\left.16^{\text {th }}, 2020\right]$. Available at: https: / / www.argentina.gob. ar/coronavirus/equipos-salud.

14. Ministerio de Salud del Gobierno de la Ciudad de Buenos Aires. Coronavirus. Información para el equipo de salud. [Accessed on: June 16 ${ }^{\text {th }}, 2020$ ]. Available at: https: / / www. buenosaires.gob.ar/coronavirus/equipos-salud.

15. Verbeek JH, Rajamaki B, Ijaz S, Sauni R, et al. Personal protective equipment for preventing highly infectious diseases due to exposure to contaminated body fluids in healthcare staff. Cochrane Database Syst Rev. 2020; 4(4):CD011621.

16. BarrettES, Horton DB, Roy J, Gennaro ML, et al. Prevalence of SARS-CoV-2 infection in previously undiagnosed health care workers at the onset of the U.S. COVID-19 epidemic. Preprint. medRxiv. 2020; 2020.04.20.20072470.

17. Ministerio de Salud, Gobierno de la Ciudad Autónoma de Buenos Aires. Unidades Febriles de Urgencia (UFU). [Accessed on: June 16 $\left.{ }^{\text {th }}, 2020\right]$. Available at: https: / / www. buenosaires.gob.ar/coronavirus / unidades-febriles-deurgencia-ufu.

18. Ferrero F, Ossorio MF, Torres FA, Debaisi G. Impact of the COVID-19 pandemic in the paediatric emergency department attendances in Argentina [published online ahead of print, 2020 Jun 18]. Arch Dis Child. 2020; archdischild-2020-319833.

19. Munro APS, Faust SN. Children are not COVID-19 super spreaders: time to go back to school. Arch Dis Child. 2020; 105(7):618-9.

20. Galan I, Velasco M, Casas ML, Goyanes MJ, et al. SARS-CoV-2 seroprevalence among all workers in a teaching hospital in Spain: unmasking the risk. medRxiv 2020.05.29.20116731. 